\title{
Laryngeal Carcinoma
}

National Cancer Institute

\section{Source}

National Cancer Institute. Laryngeal Carcinoma. NCI Thesaurus. Code C4855.

Carcinoma that arises from the laryngeal epithelium. More than 90\% of laryngeal carcinomas are squamous cell carcinomas. The remainder are adenoid cystic carcinomas, mucoepidermoid carcinomas and carcinomas with neuroendocrine differentiation. 